University for Business and Technology in Kosovo

UBT Knowledge Center

UBT International Conference

2014 UBT International Conference

Nov 8th, 9:00 AM - 9:15 AM

\title{
Strategic management of the labor market in the republic of Macedonia
}

Sejdi Xhemaili

State University of Tetova, sejdi_xh@hotmail.com

Nehat Ramadini

University for Business and Technology, nehat.ramadani@ubt-uni.net

Follow this and additional works at: https://knowledgecenter.ubt-uni.net/conference

Part of the Business Commons

\section{Recommended Citation}

Xhemaili, Sejdi and Ramadini, Nehat, "Strategic management of the labor market in the republic of Macedonia" (2014). UBT International Conference. 41.

https://knowledgecenter.ubt-uni.net/conference/2014/all-events/41

This Event is brought to you for free and open access by the Publication and Journals at UBT Knowledge Center. It has been accepted for inclusion in UBT International Conference by an authorized administrator of UBT Knowledge Center. For more information, please contact knowledge.center@ubt-uni.net. 
$3^{\text {rd }}$ International Conference on Business, Technology and Innovation

\title{
Strategic management of the labor market in the republic of Macedonia
}

\author{
${ }^{1}$ Sejdi Xhemaili, ${ }^{2}$ Nehat Ramadani \\ ${ }^{1}$ Business Administration Faculty, State University of Tetova, Macedonia \\ ${ }^{2}$ University for Bussiness and Technology -Prishtina, Kosova \\ ${ }^{1}$ sejdi_xh@hotmail.com, ${ }^{2}$ nehat.ramadani@ubt-uni.net
}

\begin{abstract}
The problems in the labor market include employment, unemployment, percentage of coverage and salary. Employment, that is, the level of unemployment emerges as a major problem in the Republic of Macedonia as well as elsewhere in the region (including also Slovenia, Albania and Kosovo). The reason for the existence of such problems in the area of the labor market is the global economic crisis. In order to mitigate the consequences of this strategic management of human resources or the unemployed work force on market, strengthening the employees with upgrading skills should apply. In this paper few examples of strategic management in Slovenia are considered - because it is closer to the region and its progress and developments will be compared to the current situation in the Republic of Macedonia. All these activities directly affect the region because an increase of the employment in one country would reduce outflow of labor abroad. In March 2005 the European Council brough the Lisbon Strategy in which it which is a guidance and offers policy recommendations to overcome the labor employment problems across Europe. More recently, A strategic policy paper called Europe 2020 aims the growth and improvement of the labor, which is adopted by the European Council. In this paper, the impact and application of EU2020 over the Republic of Macedonia is considered and examples from the region will are presented. This paper also gives concrete recommendations for improvement of unemployment issues in the Republic of Macedonia.
\end{abstract}

Keywords: strategic management, labor market, employment, unemployment

\section{Introduction}

The global economic crisis within Europe and the European Economic Community led to the crisis in the labour market. The extent of the financial crisis adds a special degree of uncertainty about the future of the world economy. In Europe to overcome the crisis it is necessary to strengthen the human capital and the level of employment opportunities through skills upgrading or retraining. This situation reflected on the Balkans too, and especially influenced the countries in transition which include the Republic of Macedonia, Albania and Kosovo. The low level of employment that is the very high degree of unemployment emerges as a major problem in the Republic of Macedonia and also wider in the region; this includes Albania and Kosovo as close neighbours who also have this problem.

\section{Strategic management of the labour market in Slovenia}

According to the $\mathrm{OECD}^{14}$ data in the Republic of Slovenia $18 \%$ of the workers are employed part-time which is as a very high percentage because the OECD average is $14 \%$. The number of people with permanent employment is very low only one in five new jobs were in 2012. And this trend has been going on for a long time. Until April 2013 Republic of Slovenia had one of the most restrictive legislation on protection of full time employment in the OECD, and the employers had no direct cost when they have terminated the part-time employment contracts when they expire.

\footnotetext{
${ }^{14}$ Slovenia a reforms for a strong and sustainable recovery, оецд, мај 204
} 


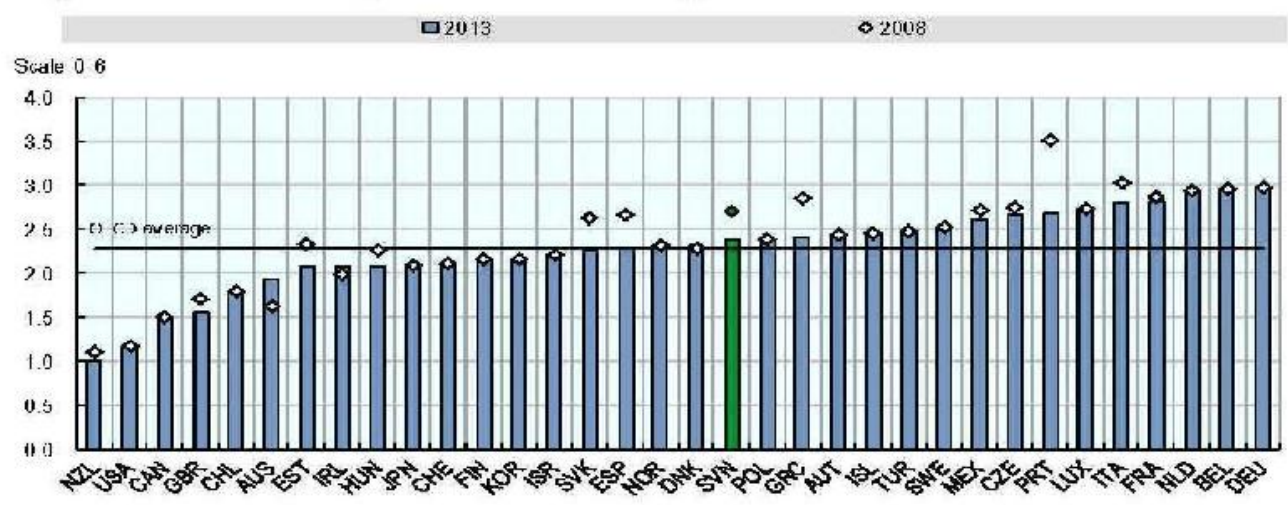

Fig. 1. Protection of workers with full-time employment from individual and collective dismissals

Source: OECD Database on employment protection

In the last ${ }^{15}$ "National reform program" in Slovenia further activities are included that will be undertaken to further improve the labour market through the application of strategic management.

The National Assembly at its session in March 2013 adopted a reform of the labour market in the form of a new Act for Labour Relations and an Act with which it amends the act for labour relationsThe new changes in the field of labour relations incorporated a number of changes and the goals of the new legislation are:

- to establish an essential concept of flexibility and security;

- to decrease the segmentation of the labour market

- to improve the efficiency of protection by the labour legislation and to prevent abuses

- to align the legislation with the decisions of the Constitutional Court of the Republic of Slovenia and other legislation and international regulations in this field

Based on the OECD index for employment protection of full time employed workers from 2008 which was - 2.98, Slovenia had one of the worst ratings of the Member States in this area. According to the calculations of the Slovenian Institute for Macroeconomic Analysis and Development, using the same methodology, the measures envisaged by the reform of the labour market will reduce the index of employment protection of full time employed workers by 2, which is the average of the Member States of OECD.

The Approximation of the indexes for employment protection of full time employed workers and workers with part-time employment will be parallel to other measures in order to reduce the differences between the various forms of work, which will further stimulate the reduction of segmentation in the labour market.

These strategic measures are expected to improve the situation of the labour market in the Republic of Slovenia. Comparatively speaking there is a slight decrease in the unemployment rate in the Republic of Slovenia ${ }^{16}$ in the period October - December 2013 and January-February 2014, and the following indicators point to it:

Table 1 Employment indicators in Slovenia

\section{X-XII 2013}

I-III 2014

\footnotetext{
${ }^{15}$ National reform program, slovenia, 2013 - 2014, мај 2013 година

${ }^{16} \mathrm{http}: / /$ www.stat.si/eng/novica_prikazi.aspx $? \mathrm{id}=6429$
} 
$3^{\text {rd }}$ International Conference on Business, Technology and Innovation

\begin{tabular}{lllllll}
\hline & total & men & women & total & men & women \\
\cline { 2 - 6 } & 0.8 & 0.1 & 1.6 & .3 & .5 & 0.2 \\
$\begin{array}{l}\text { unemployme } \\
\text { nt rate }\end{array}$ & & & & & \\
\hline $\begin{array}{l}\text { activity rate } \\
\text { employment }\end{array}$ & 7.1 & 2.5 & 2.0 & 8.3 & 3.5 & 3.2 \\
\hline rate & 0.9 & 6.1 & 5.9 & 2.9 & 8.1 & 7.7 \\
\hline
\end{tabular}

Source: SURS

\section{Unemployment at European union}

According to analysis conducted in $2013^{17}$ the unemployment rate in Germany was $5.3 \%$, Spain $2.4 \%$, in Austria it had a low percentage of $4.9 \%$ and in the United Kingdom was $7.6 \%$. This occurrence of high unemployment in some EU countries could partly be due to the failure of the EU institutions especially in the euro zone. (Figure 2). The process of EU policy aims at achieving consensus and therefore it can be slow. This leads to a focus on long-term policies in order to encourage employment and reduce unemployment. As can be seen from Figure 2, some countries have been more successful than others in maintaining a low rate of long-term unemployment, and thus suggesting that there is a room for the states to learn from each other.

However policies and institutions that would be dealt with the unemployment in short terms were not implemented and short-term policy may have worsened the unemployment condition.

- 2013 -30 year average (1984-2013)

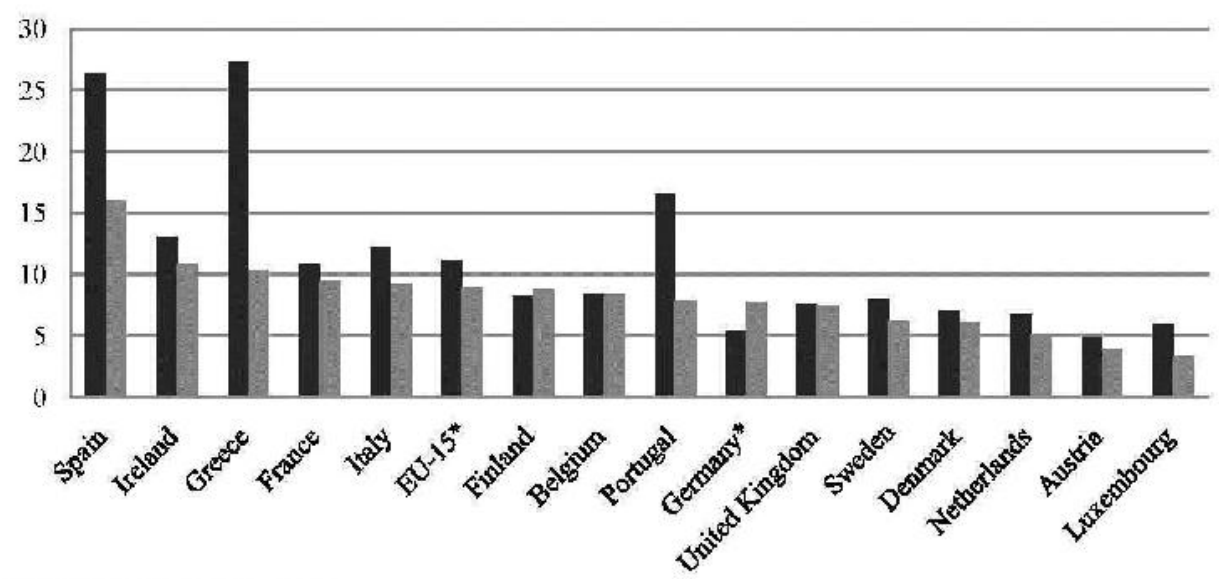

Figure 2 Unemployment rates for the EU-15

Source: AMECO Database 2014

Up until recently, issues related to employment and unemployment were addressed at European level using the "Open method of coordination" which is intergovernmental in nature. This is a form of "soft law" and thus it is not binding to the governments.

\footnotetext{
${ }^{17}$ http://www.workingnotes.ie/index.php/item/unemployment-and-the-european-union
} 
As a result of the economic crisis Directorate General for Economic and Financial Affairs Department took a greater role in relation to employment. In December 2011, in response to the then serious risk of collapse of the euro zone, were introduced a number of new measures that were called "six pack". The purpose of these measures is to strengthen economic governance in the EU, including the possibility of the EU Commission to punish member states that fail to comply with EU rules on macroeconomic policy.

One element of the "six pack" was Macroeconomic Imbalance Procedure "(MIP). A total of eleven indicators were included in the results table for MIP. Among them was the average unemployment rate over the past three years, and the member states had to maintain this rate below the level of 10 present.

Policies regarding unemployment mostly remain responsibility of the national governments. It is appropriate, particularly in terms of long-term structural features of unemployment, as it is in the interest of the national governments to keep the unemployment low. Low structural unemployment in one country does not lead to high unemployment rate in another, so there is no special need to centralize policy in order to prevent making "beggar thy neighbour" policies.

Voluntary benchmarking across states in order to see which policies best lead to substantially lower unemployment is an appropriate course of action, and that is what is being done at the moment.

\section{Lisbon strategy (March 2005) and Europe 2020}

The aim of the Lisbon Special European Council ${ }^{18}$ on 23-24 March 2000 was to strengthen Community policies, recognizing the good economic environment for creation in the Member States. Therefore it was suitable to take long-term measures based on this condition. Two recent events profoundly changed the economy and society. Globalization means that Europe must dictate the pace in all sectors where competition is intensifying. Sudden arrival and the growing importance of information and communication technologies (ICT) in the professional and private life called for a radical overhaul of the educational system in Europe and ensure lifelong learning. Therefore the European Council in Lisbon sought to issue guidelines for use of the potential offered by the new economy, in order to eradicate the evil of unemployment, among other goals. Because the processes of Cardiff, Cologne and Luxembourg together provide a number of suitable instruments, new processes are not considered necessary in Lisbon. On the contrary, through a strategic management of the adaptation and strengthening of the existing processes for potential economic growth, jobs and social cohesion can best develop - for example appropriate measures can be taken by providing the European Union with reliable data to compare them between the Member States. Due to the favourable economic outlook, full employment seemed tangible in 2000. However because of the economic crisis and structural problems of the Member States, the European Union is still lagging regarding to this aim.

The weaknesses of the European labour market continue to create difficulties:

- insufficient number of jobs are created in the service sector, although this is by far one of the most important in terms of employment;

- significant regional imbalances, particularly since the enlargement in 2004;

- high rate of long-term unemployment;

- the offer of work force does not meet the demand, which is quite often case in times of economic recovery;

- lack of women participating in the labour market;

- European demographic trends, particularly the aging population.

18

http://europa.eu/legislation_summaries/employment_and_social_policy/community_employment_polici es/c10241_en.htm 
All these weaknesses can be corrected as long as resources are available. Now, when the economic recovery has provided more room for manoeuvre, it is time to prepare for technological and social challenges. Not only these challenges have to faced, but they must also serve as a springboard towards achievement of the goal of full employment.

When taking stock five years after the launch of the Lisbon strategy, the Commission found out that the results to date are somewhat disappointing, and the European economy failed to deliver the expected performance in terms of growth, productivity and employment. Job creation is slow and there is still not enough investment in research and development.

Based on the documents of the Commission ${ }^{19}$ and in relation to the work carried out by the Council, the European Council launched the second cycle of the renewed Lisbon strategy for growth and jobs for the period 2008-2010, i.e. the Community Lisbon Programme (CLP). The European Council confirmed integrated guidelines and recommendations for each country. It also confirmed the four priority areas of the renewed Lisbon strategy: investing in knowledge and innovation; unlocking business potential, especially of the small and medium enterprises (SMEs), and modernization of the labour markets; and development of energy-efficient low-carbon economy. Based on the measures proposed by the Commission in the statement from 11 December 2007 entitled "The renewed Lisbon strategy for growth and jobs: launching the new cycle (2008 -2010)" and the work of the European Parliament and the Council, the European Council also approved a number of specific measures to be implemented.

However, these efforts were also not successful because the need for mixed policies that are present in Europe was not recognized. So, on 26th March 2010 on the proposal of the European Commission, European Council adopted the Europe 2020 program for the development and improvement of the labour market. ${ }^{20}$ The objectives of the new guideline for high quality and sustainable employment growth include:

- Increase of social productivity by increasing the rate of employment in the Member States in accordance with the increase of the quality of employment and working conditions.

- Establishing effective management of demand through coordinated economic, financial and monetary policy.

- Introduction or consolidation of an active policy on the labour market based on innovative combinations to promote the training and qualification, progressive incentives for employers to reconcile work and family life and options for sharing the work or task rotation.

- Promote social integration of people with disabilities through employment.

- Development of uniform indicators to measure »decent work«.

European Employment Strategy provides a framework for EU countries to share information, discuss and coordinate their employment policies. In this framework employment guidelines provide a common priorities and targets for the employment policies. Guidelines for the employment policies of the Member States are intrinsically linked with the guidelines for the economic policies of the Member States and the EU. Together, they form an integrated guidelines based on Strategy 2010 - Europe 2020 for smart, sustainable and inclusive growth. Integrated Guidelines include six broad economic policy guidelines (No. 1 to 6) and four guidelines for employment (No. 7 to 10) which are as follows:

- Guideline 7: Increasing labour market participation of women and men, reducing structural unemployment and promoting job quality;

- Guideline 8: Developing a skilled workforce responding to labour market needs and promoting lifelong learning;

- Guideline 9: Improving the quality and performance of education and training systems at all levels and increasing participation in tertiary or equivalent education;

19

http://europa.eu/legislation_summaries/employment_and_social_policy/eu2020/growth_and_jobs/c11 325_en.htm

20 "Europe 2020" - Proposals for the Post-Lisbon Strategy, Progressive policy proposals for Europe's economic, social and environmental renewal, Severin Fischer, Stefan Gran, Björn Hacker, Anja P.

Jakobi, Sebastian Petzold, Toralf Pusch and Philipp Steinberg, Maj 2010 
- Guideline 10: Promoting social inclusion and combating poverty.

These guidelines are to remain stable until 2014 in order to ensure a focus on their implementation.

Europe 2020, a strategy for jobs and smart, sustainable and inclusive growth, is based on five EU headline targets which are currently measured by ten headline indicators. There is an aim in it that $75 \%$ of the population aged 20-64 should be employed.

\section{The influence and applications of the current strategies in the Republic of Macedonia and the region.}

To access discussion in this field first we should look at the current state of unemployment (until March 2014).

Table 2 Employment indicators in the region

\begin{tabular}{|c|c|c|c|c|c|}
\hline $\begin{array}{l}\text { Unemployment } \\
{ }^{21} \text { in EU ( } 28 \\
\text { countries) }\end{array}$ & $\begin{array}{l}\text { Unemploym } \\
\text { ent in } \\
\text { Slovenia }\end{array}$ & $\begin{array}{l}\text { Unemployment } \\
\text { in Croatia }\end{array}$ & $\begin{array}{l}\text { Unemployment } \\
\text { in Macedonia }\end{array}$ & $\begin{array}{l}\text { Unemploy } \\
\text { ment in } \\
\text { Kosovo }^{23}\end{array}$ & $\begin{array}{l}\text { Unemploy } \\
\text { ment in } \\
\text { Albania }^{24}\end{array}$ \\
\hline $10.2 \%$ & $9.8 \%$ & 16.2 & $28.2 \%$ & $30 \%$ & $17,7 \%$ \\
\hline $\begin{array}{l}\text { Employment in } \\
\text { EU }^{25}(\mathbf{2 8} \\
\text { countries })\end{array}$ & $\begin{array}{l}\text { Employment } \\
\text { in Slovenia }\end{array}$ & $\begin{array}{l}\text { Employment in } \\
\text { Croatia }\end{array}$ & $\begin{array}{l}\text { Employment in } \\
\text { Macedonia }\end{array}$ & $\begin{array}{l}\text { Employmen } \\
\mathrm{t} \text { in Kosovo }\end{array}$ & $\begin{array}{l}\text { Employme } \\
\text { nt in } \\
\text { Albania }\end{array}$ \\
\hline $62,5 \%$ & $63 \%$ & $49.7 \%$ & $41.1 \%$ & $28,4 \%$ & $50,5 \%$ \\
\hline $\begin{array}{l}\text { Activity rate of } \\
\text { the population }\end{array}$ & $\begin{array}{l}\text { Activity rate } \\
\text { of the } \\
\text { population }\end{array}$ & $\begin{array}{l}\text { Activity rate of } \\
\text { the population }\end{array}$ & $\begin{array}{l}\text { Activity rate of } \\
\text { the population }\end{array}$ & $\begin{array}{l}\text { Activity } \\
\text { rate of the } \\
\text { population }\end{array}$ & $\begin{array}{l}\text { Activity } \\
\text { rate of the } \\
\text { population }\end{array}$ \\
\hline $64.1 \%$ & $66.2^{26 \%}$ & $68.5 \%$ & $57,3 \%$ & $0,5 \%$ & $1,3 \%$ \\
\hline
\end{tabular}

Source: Condition of employment, unemployment within EU countries and certain countries after recovery from the global economic crisis

The table shows that the lowest rate of unemployment is present in the Republic of Slovenia and as already noted above the Republic of Slovenia strives to meet the guidelines of the EU Commission and in the past it has shown an improvement in this respect. What we are interested in are our immediate neighbours and those are Albania and Kosovo. In Albania, the Government ${ }^{27}$ adopted a strategy for

21

http://epp.eurostat.ec.europa.eu/tgm/table.do?tab=table\&language=en\&pcode=teilm020\&tableSelecti on=1\&plugin=1(податоците се за 2014-август)

${ }^{22}$ http://www.stat.gov.mk/OblastOpsto.aspx?id=14(податоци за 2квартал 2014)

${ }^{23}$ file:///C:/Users/ASUS-

P8H61/Downloads/REZULTATET\%20E\%20ANKETES\%20SE\%20FUQISE\%20PUNETORE\%202

013\%20NE\%20KOSOVE.pdf(податоците се однесуваат за 2013 година)

${ }^{24}$ http://www.instat.gov.al/media/252967/lfs t2 - 2014 _.pdf(1 квартал 2014)

${ }^{25} \mathrm{http}: / /$ epp.eurostat.ec.europa.eu/tgm/table.do?tab=table\&language=en\&pcode=tsdec $420 \&$ tableSelect ion $=3 \&$ footnotes=yes\&labeling=labels\&plugin=3a (вработеноста за 2013 година)

${ }^{26} \mathrm{http} / / /$ www.stat.si/eng/novica_prikazi.aspx $? \mathrm{id}=6429$

${ }^{27}$ ALBANIA Country information note 2010 -2012 
employment 2007-13. The strategy aims to reduce the unemployment rate in Albania by 2013 to a level that can be compared with the EU Member States by improving employment policy and the VET system. Measures included in the strategy consists of establishment of a modern employment service in the country, setting a modern VET system that can contribute to the continuous development of the skills of youth and adults, providing opportunities for vocational training and vocational qualifications and involving about $20 \%$ of the registered jobseekers in active training and retraining programs, as well as encouraging lifelong learning.

Unemployment was determined to decline by $0.3 \%$ each year and the number of employed people should increase by 5\% annually. The social partners participate, among other things, in the work of the National Labour Council, which decides on the budget for various employment policies. In the field of initial and continuous training they collaborated with the ministries of Education and Labour to establish Albanian qualification system.

That these efforts were helpful to Albania shows the table above. Unfortunately it cannot be said of the Republic of Macedonia and Kosovo - the unemployment rate here is almost the same. So without further review and analysis of the existing situation, any segment of the Lisbon strategy cannot be implemented. The problems must be accurately determined and diagnosed to be able to intervene in this segment. The transition period pulled back both, Macedonia and Kosovo, halting production capacity has led to a large number of unemployed people in both countries. Somehow a suitable solution to mitigate this problem cannot be found - especially in the Republic of Macedonia. As a good example can serve the guidelines used by the Republic of Slovenia to reach the desired - and that is to reduce the percentage of unemployed people.

\section{Conclusions and policy reccomandation}

The Government of the Republic of Macedonia must work on segments such as education of people, training, retraining and various courses, it should also motivate the employers with, for example, giving certain tax relieves at employment of more people, and all those elements that should be determined by examining the situation in the field, if there is a desire to come out of the shackles of high unemployment soon;

Implementation of active policies on the labour market which will be focused on strengthening the support to young long-term unemployed, women, low-skilled, unregistered workers and other vulnerable groups;

It is necessary to work more in the education sector, that is, creation of cadres who cannot find work because there are many people with the same level of education;

Further improvement of the business climate, competitiveness and increase of investments. Improvement of the mechanisms of the labour market, such as determination of wages, social security, social security system, creating conditions for adjustment of work with the private life.

\section{References}

1. Europe 2020" - Proposals for the Post-Lisbon Strategy, Progressive policy proposals for Europe's economic, social and environmental renewal, Severin Fischer, Stefan Gran, Björn Hacker, Anja P. Jakobi, Sebastian Petzold, Toralf Pusch and Philipp Steinberg, Maj 2010

2. Slovenia a reforms for a strong and sustainable recovery, оецд, мај 204

3. http://epp.eurostat.ec.europa.eu/tgm/table.do?tab=table\&language=en\&pcode=teilm020\&tabl eSelection=1\&plugin=1(податоците се за 2014-август)

4. http://www.instat.gov.al/media/252967/lfs_t2__2014_-.pdf(1 квартал 2014)

5. http://epp.eurostat.ec.europa.eu/tgm/table.do?tab=table\&language=en\&pcode=tsdec420\&tabl eSelection=3\&footnotes=yes\&labeling=labels\&plugin=3а (вработеноста за 2013 година)

6. http://www.stat.si/eng/novica_prikazi.aspx?id=6429, ALBANIA Country information note $2010-2012$ 